\title{
Transformations technologiques et vulgarisation scientifique
}

Histoire des apprentissages précoces - imaginaire et activité technique

Michèle Salmona

\section{(2) OpenEdition}

\section{Journals}

Édition électronique

URL : https://journals.openedition.org/tc/1042

DOI : $10.4000 /$ tc. 1042

ISSN : $1952-420 X$

\section{Éditeur}

Éditions de l'EHESS

Édition imprimée

Date de publication : 1 juin 1983

ISSN : 0248-6016

\section{Référence électronique}

Michèle Salmona, «Transformations technologiques et vulgarisation scientifique », Techniques \&

Culture [En ligne], 1 | 1983, mis en ligne le 26 janvier 2006, consulté le 29 septembre 2022. URL : http:// journals.openedition.org/tc/1042 ; DOI : https://doi.org/10.4000/tc.1042

Ce document a été généré automatiquement le 29 septembre 2022.

Tous droits réservés 


\section{Transformations technologiques et vulgarisation scientifique}

Histoire des apprentissages précoces - imaginaire et activité technique

Michèle Salmona 